Скаковська C. C. ${ }^{[1 ; 0 R C I ~ I D: ~ 0000-0002-3415-9613], ~}$ ст. викладач

${ }^{1}$ Національний університет водного господарства та природокористування, м. Рівне

\title{
АНАЛІЗ ЕКОНОМІКО-ЕКОЛОГІЧНОГО СТАНУ РЕГІОНІВ УКРАЇНИ
}

Екологічну ситуацію в Україні, яка склалась на сьогодні, можна охарактеризувати як кризову. Вона формувалася протягом тривалого періоду через недотримання законів розвитку і відтворення природноресурсного потенціалу, перевага надавалася розвитку в Україні сировинно-видобувних, найбільш екологічно небезпечних галузей промислового комплексу. Значні зміни, які відбувалися у структурі народного господарства, не призвели до зменшення антропогенного впливу на довкілля.

Ключові слова: регіон; природокористування; забруднення; антропогенний вплив.

Вступ. Україні притаманна висока питома вага ресурсномістких та енергоємних технологій, впровадження та нарощування яких здійснювалося найбільш простим та примітивним способом - без облаштування необхідних очисних споруд та обладнання. Це було допустимим за відсутності діючих правових, адміністративних та економічних механізмів природокористування та без урахування вимог охорони довкілля.

Аналіз останніх досліджень. Вивченню питань природокористування присвячені праці багатьох зарубіжних та вітчизняних вчених. Так, серед вчених значний внесок у дослідження цього питання зробили такі вітчизняні науковці, як Борисова В. А. [1], Гаман П. І. [2], Герасимчук 3. В. [3], Голян В. А. [4; 8], Данилишин Б. М. [4], Кадацький М. О. [7], Кашенко О. Л. [5], Нєсвєтов О. О. [7], Поліщук В. Г. [3], Стеченко Д. М. [6], Хвесик М. А. [4], Царенко О. М. [7], Черчик Л. М., Шубалий О. М.

Метою дослідження $€$ аналіз значень антропогенних впливів діяльності людини у сфері природокористування на складові довкілля за регіонами України.

Постановка завдання. Природокористування $є$ тією сферою господарських відносин, де більш ніж в інших галузях національної економіки має бути сформовано досконалий організаційноекономічний механізм господарювання, адже саме природні ресурси та природні умови становлять основу життєдіяльності населення. В умовах відсутності дієвих та результативних важелів раціонального 
природокористування підприємницькі структури в пошуках рентних доходів у стратегію своєї діяльності аж ніяк не вмонтовують екологічні імперативи.

Результати дослідження. Природокористування - сфера виробничої та наукової діяльності, вся сукупність засобів, які застосовує суспільство задля комплексного вивчення, освоєння, використання, відновлення, поліпшення й охорони природного середовища та природних ресурсів з метою розвитку продуктивних сил, забезпечення сприятливих умов життєдіяльності людини. Це сукупність усіх впливів людства на природу, яка включає заходи з їі освоєння, перетворення і охорони [1].

Раціоналізація природокористування передбачає розгляд природних процесів і виробничої діяльності як єдиної біоекономічної системи. Істотне погіршення якості навколишнього середовища, що значною мірою пов'язано зі зростанням масштабів антропогенного впливу, зумовило потребу формування природокористування, що забезпечить об'єктивне уявлення про обсяги природних ресурсів, якість навколишнього середовища, інтенсивність та напрямки техногенного навантаження на природу.

Природокористування $€$ важливою складовою національного господарського комплексу, адже забезпечує імплементацію господарського використання природних ресурсів та охорони довкілля в чинник соціально-економічного піднесення.

М.Ф. Реймерс визначає природокористування як сукупність усіх форм експлуатації природно-ресурсного потенціалу й заходів для його збереження (видобуток і переробка природних мінеральних та біологічних ресурсів, їхнє відновлення, охорона природних умов життя, природних систем тощо). Розвиток продуктивних сил, зростання обсягів природокористування й темпів забруднення довкілля за одночасного вичерпання природних ресурсів - все це зумовило погіршення здоров'я працездатного населення, зниження продуктивності праці, зміну клімату та порушення кругообігу речовин у природі.

Винятковою особливістю екологічного стану України $\epsilon$ те, що екологічно гострі локальні ситуації поглиблюються великими регіональними кризами. Чорнобильська катастрофа 3 ї̈ довготривалими медико-біологічними, економічними та соціальними наслідками спричинила в Україні ситуацію, яка наближається до рівня глобальної екологічної катастрофи.

Проаналізуємо величини антропогенного навантаження у регіонах України на природні ресурси: атмосферне повітря, мінерально-сировинні, водні, земельні, лісові.

Атмосферне повітря. Викиди забруднюючих речовин в атмосферу від стаціонарних та пересувних джерел забруднення в 
2018 році складали 3866,7 тис. т, 3 них від стаціонарних $-64,9 \%$, від пересувних - 35,1\%.

При цьому спостерігається їх яскравий розподіл за регіонами. Так, у 2017 році Південний та Центральний регіони характеризувалися найбільшими обсягами викидів забруднюючих речовин в атмосферне повітря від стаціонарних джерел серед регіонів України. У Південному регіоні вони дорівнювали 1019,1 тис. т, що в 8,5 разів більше ніж викиди того ж року в Північному регіоні (рис. 1). На Донецьку область (Південний регіон) припадає 30,4\% викидів забруднюючих речовин в атмосферне повітря від стаціонарних джерел в Україні, на Дніпропетровську (Центральний регіон) $-25,4 \%$.

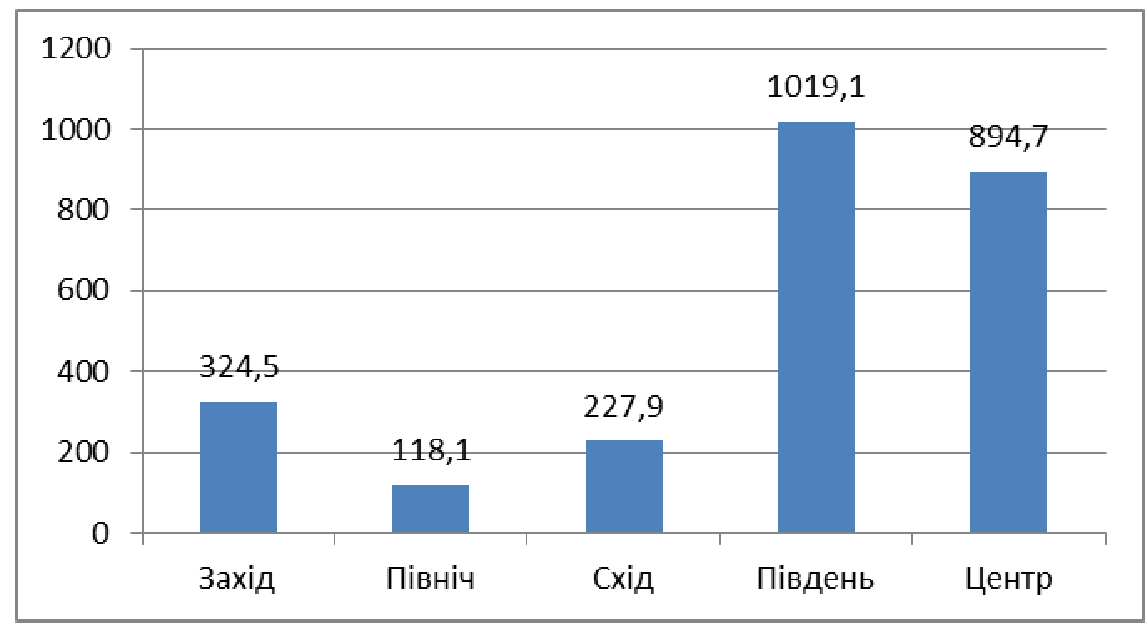

Рис. 1. Викиди забруднюючих речовин в атмосферне повітря від стаціонарних джерел забруднення за регіонами [6]

У Західному регіоні найбільша кількість викидів забруднюючих речовин (73\%) в атмосферне повітря від стаціонарних джерел припадає на постачання електроенергії, газу, пари та кондиційованого повітря [6].

У Північному регіоні половину викидів забруднюючих речовин (54\%) в атмосферне повітря від стаціонарних джерел припадає на постачання електроенергії, газу, пари та кондиційованого повітря. Переробна промисловість $€$ на другому місці (20\%).

У Східному регіоні, крім постачання електроенергії, газу, пари та кондиційованого повітря (38\%), суттєву роль в забрудненні повітря відіграє добувна промисловість (23\%) і розроблення кар'єрів (23\%).

У Південному регіоні найбільша кількість викидів забруднюючих речовин в атмосферне повітря від стаціонарних 
джерел припадає на постачання електроенергії, газу, пари та кондиційованого повітря (41\%) та на переробну промисловість (39\%) [6].

у Центральному регіоні найбільша кількість викидів забруднюючих речовин в атмосферне повітря від стаціонарних джерел припадає на переробну промисловість (45\%). Друге місце поділяють: постачання електроенергії, газу, пари та кондиційованого повітря (23\%) і добувна промисловість і розроблення кар'єрів (23\%) [6].

Рослинний світ та лісові ресурси. Тривале безконтрольне використання природних ресурсів, багатьох цінних лікарських рослин, інтенсифікація господарського використання територій 3 наявністю лікарських рослин, несприятлива екологічна ситуація в зоні 3 високим ресурсним потенціалом після аварії на Чорнобильській АЕС спричинили кризовий стан ресурсів більшості дикорослих лікарських рослин.

На сьогодні лікарські рослини ростуть на площі, що становить менше 10\% території України. В Україні в цілому близько 85\% лікарської рослинної сировини збирається в природних місцезростаннях видів лікарських рослин. 3 кожним роком збільшуються площі та різноманіття культивованих лікарських рослин, однак їх кількість, як правило, не перевищує 15 видів.

Загальний обсяг лісокористування в Україні становить 14,4 млн куб. метрів, у тому числі основного користування - 6,7 млн куб. метрів, що задовольняє потреби народного господарства лише на 25-27\%. У зв'язку з дефіцитом деревини щорічна потреба в ії завезенні становить 30 млн куб. метрів.

За даними Державного агентства лісових ресурсів, відмічається циклічний характер випадків скоєння незаконних рубок, який нерозривно пов'язаний 3 піднесенням або спадами рівнів економічної активності в Україні (рис. 2).

Кількість офіційно зафіксованих порушень є: найбільшою в Північному (3484 од.) і Західному (2706 од.) регіонах; найменшою - в Південному регіоні.

На першому місці по кількості зафіксованих незаконних рубок знаходиться Рівненська область (1676 од.). Значна кількість незаконних рубок фіксується у Львівській, Волинській та ІваноФранківській областях. Найнижча кількість (менше 40 од.) - в Миколаївській області.

Складний екологічний стан лісів зумовлюється як рівнем та інтенсивністю антропогенного впливу, так і зростаючим техногенним 
навантаженням, що порушує природну стійкість і середовищеформуючі функції лісових екосистем.

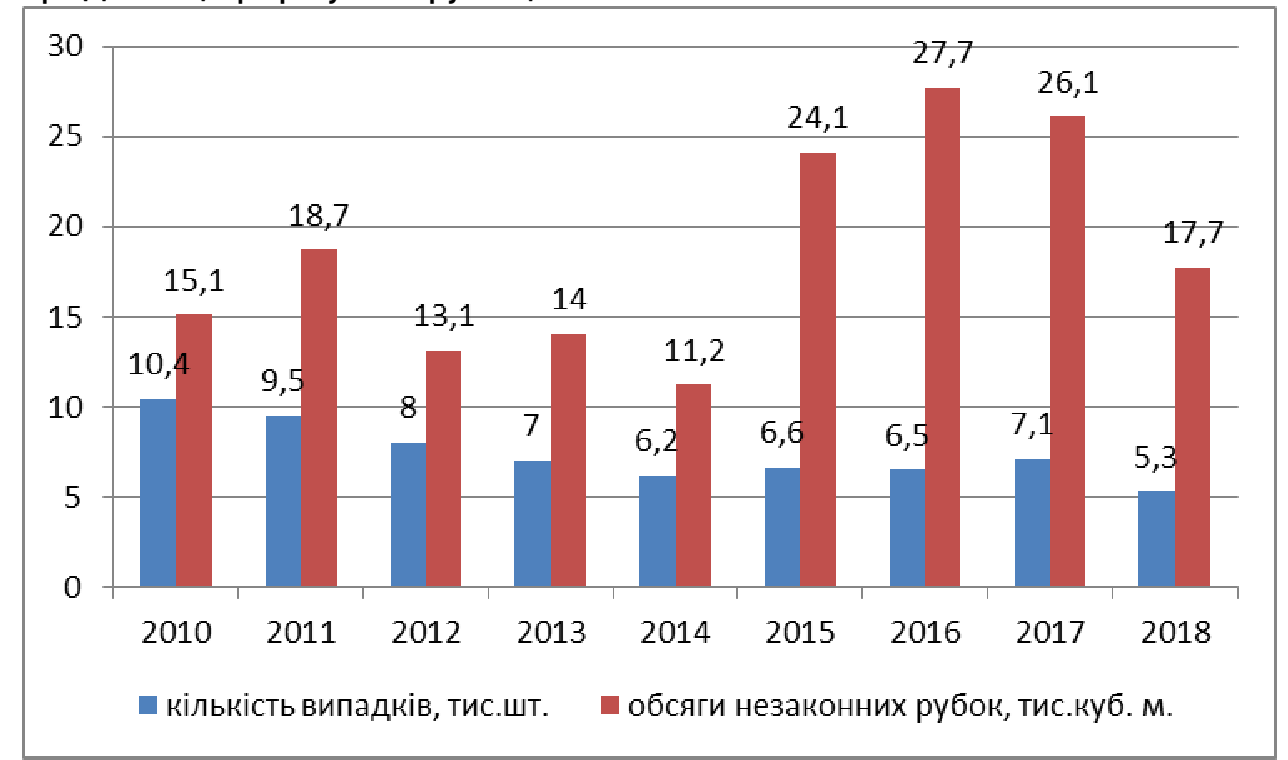

Рис. 2. Кількість і обсяги незаконних рубок 2010-2018 роки [13]

Лише за останнє десятиріччя в Україні загинуло від промислових викидів 2,5 тис. гектарів лісових насаджень, радіаційного забруднення через аварію на Чорнобильській АЕC зазнали 3,5 млн. гектарів лісів, що потребує обмеження лісокористування, удосконалення системи протипожежної безпеки лісів. В середньому щороку виникає 3500 лісових пожеж на площі 4000 гектарів.

Водні ресурси. Основні джерела прісної води на території України - поверхневі води річок Дніпра, Дністра, Південного Бугу, Сіверського Дінця, Дунаю з притоками, а також малих річок північного узбережжя Чорного та Азовського морів. Порушення норм якості води досягло рівнів, які ведуть до деградації водних екосистем, зниження продуктивності водойм.

Прогнозні ресурси підземних вод питної якості розподілені на території України вкрай нерівномірно і становлять 22,5 млрд куб. метрів на рік (61,7 млн куб. метрів на добу), з яких 8,9 млрд куб. метрів (24,4 млн куб. метрів на добу) гідравлічно не зв'язані 3 поверхневим стоком і становлять додаткову складову до поверхневого стоку. Водозабір підземних вод у складі прогнозних ресурсів становить 21 відсоток, що свідчить про можливість ширшого використання їх у багатьох областях.

Витрати свіжої води в Україні на одиницю виробленої продукції значно перевищують такі показники у розвинутих країнах Європи: Франції - в 2,5 рази, ФРН - в 4,3, Великобританії та Швеції - в 


\section{4,2 рази.}

Забезпечення водою населення України в повному обсязі ускладнюється через незадовільну якість води водних об'єктів.

Якість води більшості з них за станом хімічного і бактеріального забруднення класифікується як забруднена і брудна (IV-V клас якості). Найгостріший екологічний стан спостерігається в басейнах річок Дніпра, Сіверського Дінця, річках Приазов'я, окремих притоках Дністра, Західного Бугу, де якість води класифікується як дуже брудна (VI клас). Для екосистем більшості водних об'єктів України властиві елементи екологічного та метаболічного регресу.

Основними причинами забруднення поверхневих вод України $€$ скид неочищених та не досить очищених комунально-побутових і промислових стічних вод безпосередньо у водні об'єкти та через систему міської каналізації; надходження до водних об'єктів забруднюючих речовин у процесі поверхневого стоку води 3 забудованих територій та сільгоспугідь; ерозія ґрунтів на водозабірній площі.

Скид забруднюючих речовин підприємств промисловості та комунального господарства, а також стоки з сільськогосподарських територій і територій, зайнятих сміттєзвалищами, мають значний негативний вплив на водні об'єкти.

Частка забруднених у загальній кількості скинутих вод у водні об'єкти в середньому по Україні досягає 20,3\%.

Найбільший \% забруднених вод у загальній кількості скинутих вод у водні об'єкти спостерігається у Північному - $30 \%$ і Центральному - 27,4\% регіонах (рис. 3 ).

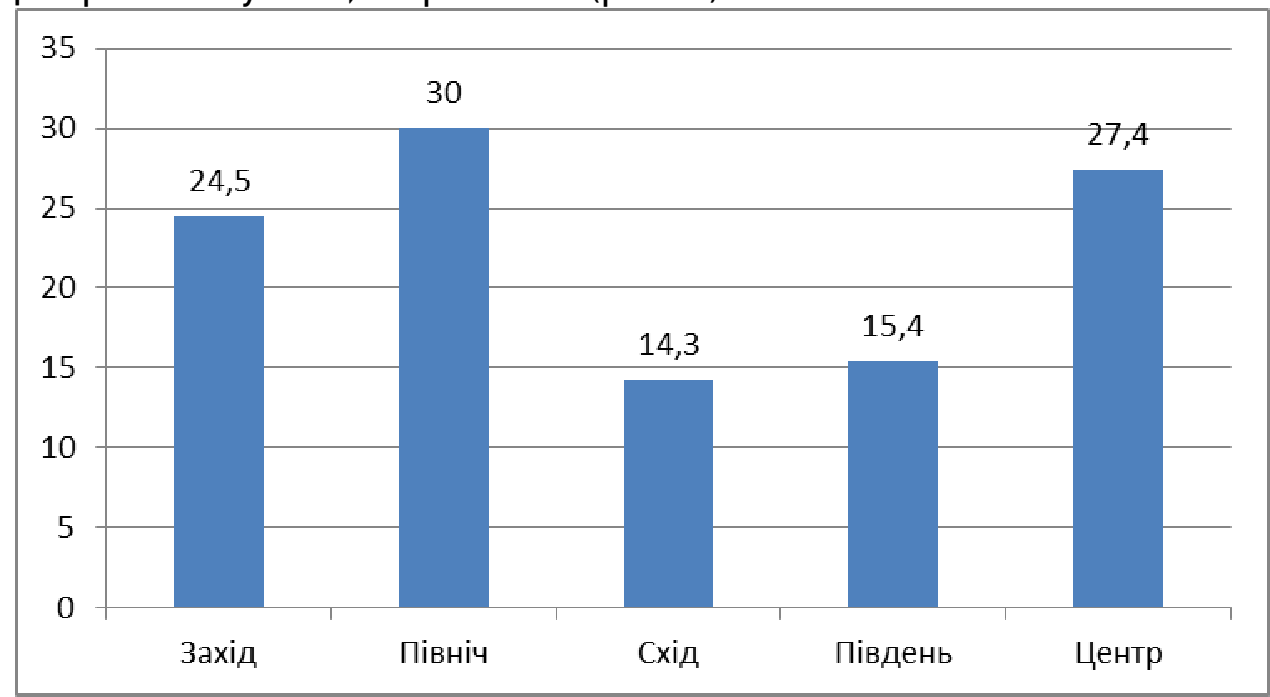

Рис. 3. Частка забруднених вод у загальній кількості скинутих вод у водні об'єкти за регіонами України, (\%), [7] 
Якісний стан підземних вод внаслідок господарської діяльності також постійно погіршується. Це пов'язано з існуванням на території України близько 3 тис. фільтруючих накопичувачів стічних вод, а також з широким використанням мінеральних добрив та пестицидів.

Найбільш незадовільний якісний стан підземних вод у Донбасі та Кривбасі. Значну небезпеку в експлуатаційних свердловинах Західної України становить наявність фенолів (до 5-10 ГДК), а також підвищення мінералізації та зростання вмісту важких металів у підземних водах Криму.

Головні чинники забруднення підземних вод в Україні: комунальні стоки, стоки тваринницьких комплексів, мінеральні добрива, продукти сільгоспхімії, свинець, марганець, нафтопродукти.

На сьогодні спостерігається формування стійких осередків забруднення підземних вод, які пов'язані з місяцями концентрації промисловості і населення (Дніпропетровська, Луганська та Запорізька області), а також із місцями використання мінеральних та органічних добрив і пестицидів (Черкаська, Миколаївська, Херсонська, Одеська) (рис. 4).

На першому місці за кількістю осередків забруднення $\epsilon$ Центральний регіон (61 одиниця).

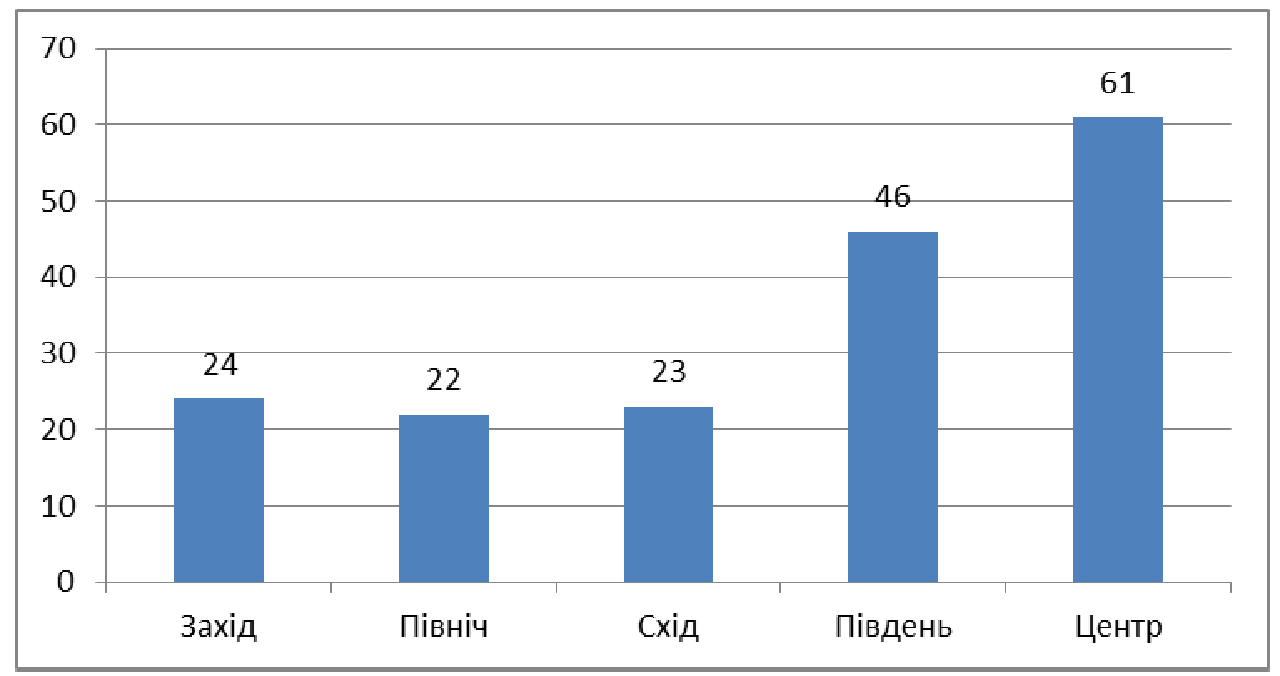

Рис. 4. Розподіл основних осередків забруднення підземних вод за регіонами України, 2017 (од), [10]

Проблема екологічного стану водних об'єктів $є$ актуальною для всіх водних басейнів України. Що ж до Дніпра, водні ресурси якого становлять близько 80\% водних ресурсів України і забезпечують водою 32 млн населення та 2/3 господарського потенціалу країни, то це одне 3 найважливіших завдань економічного і соціального 
розвитку та природоохоронної політики держави. Це зумовлено складною екологічною ситуацією на території басейну, оскільки 60\% iï розорано, на $35 \%$ земля сильно еродована, на $80 \%$ трансформовано первинний природний ландшафт.

Водосховища на Дніпрі стали накопичувачами забруднюючих речовин. Значної шкоди завдано північній частині басейну внаслідок катастрофи на Чорнобильській AEC; в критичному стані перебувають малі річки басейну, значна частина яких втратила природну здатність до самоочищення. У катастрофічному стані знаходяться річки Нижнього Дніпра, де щорічно має місце ускладнення санітарно-епідеміологічної ситуації, знижується вилов риби, бідніє біологічне різноманіття.

Значної шкоди екосистемі Дніпра поряд із щорічним забрудненням басейну органічними речовинами (40 тис. тонн), нафтопродуктами (745 тонн), хлоридами, сульфатами (по 400 тис. тонн), солями важких металів (65-70 тонн) завдає забруднення біогенними речовинами внаслідок використання відсталих технологій сільськогосподарського виробництва, низької ефективності комунальних очисних споруд.

3 метою екологічного оздоровлення басейну річки Дніпро та збереження i відтворення водних ресурсів рішенням Київської обласної ради від 17.03.2013 № 663-34-VI (із змінами від 22.06.2017 № 352-15-VII) затверджена Обласна цільова програма розвитку водного господарства та екологічного оздоровлення басейну річки Дніпро на період до 2021 року.

Не в кращому, а подекуди і в гіршому стані перебувають басейни інших річок України (Сіверського Дінця, Дністра, Західного Бугу, Південного Бугу, басейни річок Приазовської та Причорноморської низовин). Тому мета та стратегічні напрями, визначені Національною програмою для Дніпра, є аналогічними і для інших водних басейнів України.

Земельні ресурси. Сучасне використання земельних ресурсів України не відповідає вимогам раціонального природокористування. Порушено екологічно допустиме співвідношення площ ріллі, природних кормових угідь, лісових насаджень, що негативно впливає на стійкість агроландшафту.

Відповідно до Стратегії удосконалення механізму управління в сфері використання та охорони земель сільськогосподарського призначення державної власності та розпорядження ними, понад 92\% території країни залучено для господарського використання. Дуже високим є рівень розораності території держави - понад 54\%. 
Для порівняння - у країнах Європи цей показник не перевищує $35 \%$. Фактична лісистість території України становить лише 16\%, що недостатньо для забезпечення екологічної рівноваги.

Рівень розораності сільськогосподарських угідь $є$ найвищим у Південному, Центральному і у Східному регіонах, де перевищує 70\% (рис. 5).

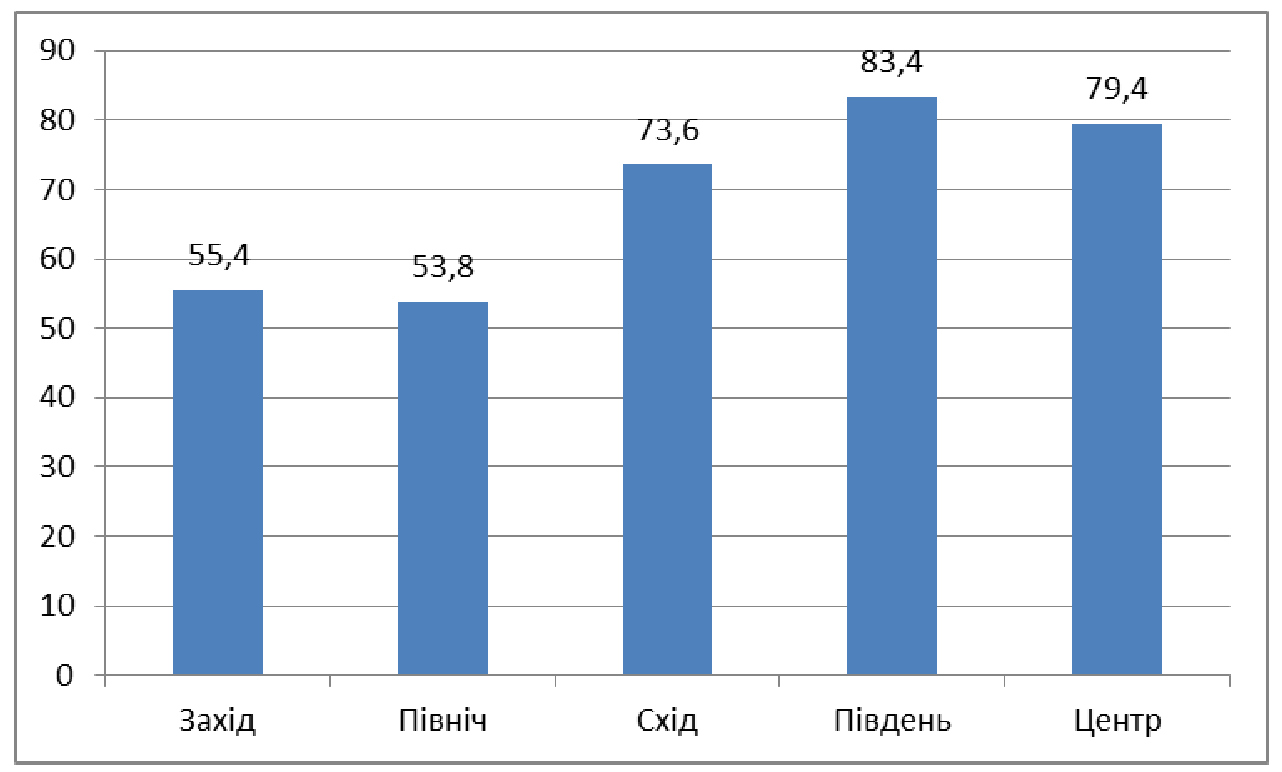

Рис. 5. Розораність сільськогосподарських угідь за регіонами України, $2017(\%),[11]$

3 ґрунтом щороку виноситься $11 \mathrm{Mлн} \mathrm{тонн} \mathrm{гумусу,} \mathrm{0,5} \mathrm{млн} \mathrm{тонн}$ азоту, 0,4 млн тонн фосфору і 0,7 млн тонн калію. Щорічні екологоекономічні збитки від ерозії ґрунтів дорівнюють 9,1 млрд гривень.

Понад $40 \%$ органіки, отримуваної в результаті діяльності великих тваринницьких комплексів та птахофабрик, з потенційних органічних добрив перетворюються на джерела забруднення довкілля.

Ситуація з забрудненням територій ускладнилася після аварії на Чорнобильській АЕС. Радіонуклідами забруднено понад 4,6 млн гектарів земель у 74 районах 11 областей, у тому числі 3,1 млн гектарів ріллі. 3 використання вилучено 119 тис. гектарів сільськогосподарських угідь, у тому числі 65 тис. гектарів ріллі.

Корисні копалини. За різноманітністю та багатством мінеральносировинних ресурсів Україна випереджає такі розвинуті країни світу, як США, Канада, Англія, Франція, Китай та інші. В Україні виробляється близько 5\% світового обсягу мінерально-сировинних 
ресурсів. Щороку гірничодобувна промисловість України випускає продукції на 25-28 млрд доларів США (у цінах світового ринку).

На території України виявлено близько 8 тисяч родовищ, понад 90 видів корисних копалин, з яких 20 мають важливе економічне значення. Серед них нафта, газ, залізні, марганцеві, титанові, уранові руди, вугілля, сірка, ртуть, каолін, графіт, вогнетривкі глини, будівельні матеріали, питні, мінеральні води.

До промислового освоєння залучено від 40 до $75 \%$ розвіданих запасів основних видів корисних копалин.

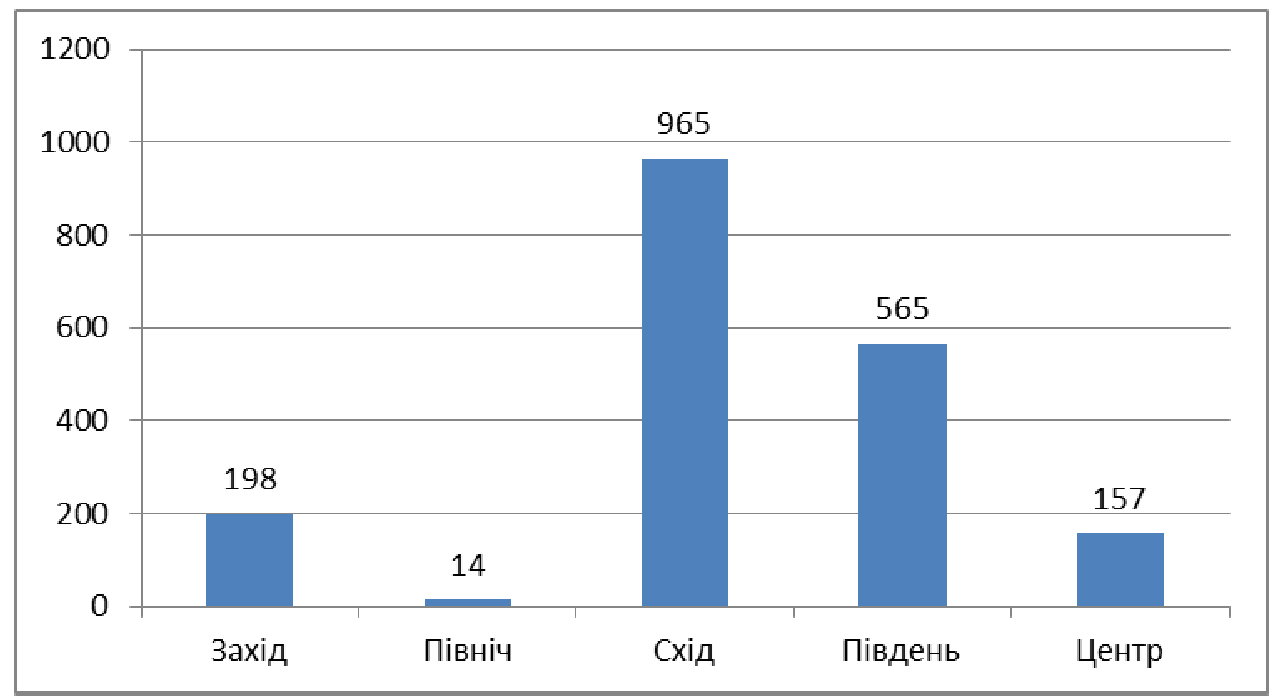

Рис. 6. Кількість об'єктів по видобутку основних корисних копалин в Україні за регіонами, 2017 [12]

Найбільша кількість об'єктів з видобутку основних корисних копалин в Україні знаходиться у Східному (965 об'єктів) і в Південному регіонах (565 об'єктів).

Потенційна вартість техногенних родовищ за попередніми розрахунками обчислюється десятками млрд. доларів США. Така маса вторинних продуктів у перерахунку на 1 кв. кілометр території України перевищує аналогічний показник для США у 6 разів та у 3 рази - для держав Європейського Союзу.

Висновок. Головними причинами, що призвели до загрожуючого стану довкілля, є: застаріла технологія виробництва та обладнання, висока енергомісткість та матеріаломісткість, що перевищують у два-три рази відповідні показники розвинутих країн; високий рівень концентрації промислових об'єктів; несприятлива структура промислового виробництва 3 високою концентрацією екологічно небезпечних виробництв; відсутність належних природоохоронних систем (очисних споруд, оборотних систем 
водозабезпечення тощо), низький рівень експлуатації існуючих природоохоронних об'єктів; відсутність належного правового та економічного механізмів, які стимулювали б розвиток екологічно безпечних технологій та природоохоронних систем; відсутність належного контролю за охороною довкілля.

Необхідно визнати, що будь-які стратегії економічного зростання на базі нових технологій, або консервація не можуть являтись дієвим механізмом вирішення економіко-екологічних проблем. Основний висновок полягає у необхідності зміни глобальної економіко-екологічної політики, що враховує особливості розвитку окремих регіонів.

Завдання полягає в тому, щоб сформувати такий організаційно економічний механізм природокористування, який би сприяв його раціоналізації, прискорював соціально економічне зростання регіонів, забезпечував соціальну ефективність використання складових «природного капіталу» у відтворювальному процесі. Крім того, розробка і застосування системи економічних регуляторів використання природних ресурсів та охорони навколишнього природного середовища - необхідний крок до розв'язання екологічних проблем в умовах ринкової трансформації.

1. Борисова В. А. Екологічні основи природокористування В АПК. Суми : Видавництво «Довкілля», 2004. 356 с. 2. Гаман П. І. Зміст економічного механізму природокористування та природоохоронної діяльності. Бізнеснавігатор. Сер. Економіка і підприємництво. 2009. № 8. 25 с. 3. Герасимчук 3. В., Поліщук В. Г. Стимулювання сталого розвитку регіону: теорія, методологія, практика : монографія. Луцьк : РВВ ЛНТУ, 2011. 516 с. 4. Данилишин Б. М., Хвесик М. А., Голян В. А. Економіка природокористування: підручник. К. : «Кондор», 2009465 с. 5. Кашенко О. Л. Екологічна сутність економічних категорій. Суми : Видавництво «Університетська книга». 2001. 132 с. 6. Довкілля України за 2017 рік: статистичний збірник / за ред. О. М. Прокопенко. Державна служба статистики України.

K., 2018.

URL: http://www.ukrstat.gov.ua/druk/publicat/kat_u/2018/zb/11/zb_du2017.pdf (дата звернення: 20.11.2020). 7. Стеченко Д. М. Управління регіональним розвитком: навч. посіб. К. : Вища шк., 2000. 223 с. 8. Стан підземних вод України : щорічник. Державна служба геології та надр України, Державне науково-виробниче підприємство «Державний інформаційний геологічний фонд України». К., 2018. 121 c. URL: http://geoinf.kiev.ua/wp/wp-content/uploads/2018/07/2017_sajt.pdf (дата звернення: 20.11.2020). 9. Стратегія удосконалення механізму управління в сфері використання та охорони земель сільськогосподарського призначення державної власності та розпорядження ними : затверджена Постановою Кабінету $\begin{array}{llllll}\text { міністрів України від } 07.06 .2017 & \text { р. № 413. URL: }\end{array}$ https://zakon.rada.gov.ua/laws/show/413-2017-\%D0\%BF\#n12 (дата звернення: 20.11.2020). 10. Мінеральні ресурси України: щорічник. Державне наукововиробниче підприємство «Державний інформаційний геологічний фонд України». K., 2018. 270 c. URL: http://geoinf.kiev.ua/M_R_2018_1.pdf (дата звернення: 
20.11.2020). 11. Охорона лісу від незаконних рубок (станом на 14.01.2019р.) : вебсайт Державного агентства лісових ресурсів України. URL: http://dklg.kmu.gov.ua/forest/control/uk/publish/article?art_id=118945 (дата звернення: 20.11.2020). 12. Царенко О. М., Нєсвєтов О. О., Кадацький М. О. Основи екології та економіка природокористування. Курс лекцій. Практикум : навч. посіб. 2-ге вид., стер. Суми : ВДТ «Університетська книга», 2004. 400 с. 13. Черчик Л. М., Голян В. А., Шубалий О. М. Економіка природокористування : навч. посіб. для підготовки бакалаврів за напрямом «Екологія та охорона навколишнього середовища». Луцьк: РВВ ЛНТУ, 2011. 528 с.

\section{REFERENCES:}

1. Borysova V. A. Ekolohichni osnovy pryrodokorystuvannia V APK. Sumy : Vydavnytstvo «Dovkillia», 2004. 356 s. 2. Haman P. I. Zmist ekonomichnoho mekhanizmu pryrodokorystuvannia ta pryrodookhoronnoi diialnosti. Biznesnavihator. Ser. Ekonomika i pidpryiemnytstvo. 2009. № 8.25 s. 3. Herasymchuk Z. V., Polishchuk V. H. Stymuliuvannia staloho rozvytku rehionu: teoriia, metodolohiia, praktyka : monohrafiia. Lutsk : RVV LNTU, 2011.516 s. 4. Danylyshyn B. M., Khvesyk M. A., Holian V. A. Ekonomika pryrodokorystuvannia : pidruchnyk. K. : «Kondor», 2009465 s. 5. Kashenko 0. L. Ekolohichna sutnist ekonomichnykh katehorii. Sumy : Vydavnytstvo «Universytetska knyha». 2001. 132 s. 6. Dovkillia Ukrainy za 2017 rik : statystychnyi zbirnyk / za red. O. M. Prokopenko. Derzhavna sluzhba statystyky Ukrainy. K., 2018. URL: http://www.ukrstat.gov.ua/druk/publicat/kat_u/2018/zb/11/zb_du2017.pdf (data zvernennia: 20.11.2020). 7. Stechenko D. M. Upravlinnia rehionalnym rozvytkom : navch. posib. K. : Vyshcha shk., 2000. 223 s. 8. Stan pidzemnykh vod Ukrainy : shchorichnyk. Derzhavna sluzhba heolohii ta nadr Ukrainy, Derzhavne naukovovyrobnyche pidpryiemstvo «Derzhavnyi informatsiinyi heolohichnyi fond Ukrainy». K., $2018 . \quad 121 \mathrm{~s}$ URL: http://geoinf.kiev.ua/wp/wpcontent/uploads/2018/07/2017_sajt.pdf (data zvernennia: 20.11.2020). 9. Stratehiia udoskonalennia mekhanizmu upravlinnia $v$ sferi vykorystannia ta okhorony zemel silskohospodarskoho pryznachennia derzhavnoi vlasnosti ta rozporiadzhennia nymy: zatverdzhena Postanovoiu Kabinetu Ministriv Ukrainy vid 07.06.2017 r. № 413. URL: https://zakon.rada.gov.ua/laws/show/413-2017-\%D0\%BF\#n12 (data zvernennia: 20.11.2020). 10. Mineralni resursy Ukrainy : shchorichnyk. Derzhavne naukovovyrobnyche pidpryiemstvo «Derzhavnyi informatsiinyi heolohichnyi fond Ukrainy». K., 2018. 270 s. URL: http://geoinf.kiev.ua/M_R_2018_1.pdf (data zvernennia: 20.11.2020). 11. Okhorona lisu vid nezakonnykh rubok (stanom na 14.01.2019 r.) : vebsait Derzhavnoho ahentstva lisovykh resursiv Ukrainy. URL: http://dklg.kmu.gov.ua/forest/control/uk/publish/article?art_id=118945 (data zvernennia: 20.11.2020). 12. Tsarenko O. M., Niesvietov 0. 0., Kadatskyi M. O. Osnovy ekolohii ta ekonomika pryrodokorystuvannia. Kurs lektsii. Praktykum : navch. posib. 2-he vyd., ster. Sumy : VDT «Universytetska knyha», 2004. 400 s. 13. Cherchyk L. M., Holian V. A., Shubalyi 0. M. Ekonomika pryrodokorystuvannia : navch. posib. dlia pidhotovky bakalavriv za napriamom «Ekolohiia ta okhorona navkolyshnoho seredovyshcha». Lutsk: RVV LNTU, 2011. $528 \mathrm{~s}$. 


\section{ANALYSIS OF THE ECONOMIC AND THE ECOLOGICAL CONDITION OF THE REGIONS OF UKRAINE}

Ukraine is characterized by a high share of resource-intensive and energy-intensive technologies, the implementation and expansion of which was carried without the installation of the necessary treatment facilities and equipment.

Atmospheric air. In 2017 the Southern and Central regions were characterized by the largest volumes of pollutants into the atmosphere, from stationary sources among the regions of Ukraine. In the Southern region they amounted to $1,019.1$ thousand tons, which is 8.5 times more than the same year's emissions in the Northern region.

Flora and forest resources. According to the State Agency of Forest Resources, there is a cyclical nature of illegal logging cases, which is inextricably linked by rising or falling levels of economic activities in Ukraine.

The number of officially recorded violations are the largest in the Northern (3484 units) and Western (2706 units) regions; the smallest - in the Southern region.

At the first place in the numbers of recorded illegal logging in Rivne region (1676 units). A significant number of illegal logging is recorded in Lviv, Volyn and Ivano-Frankivsk regions. The lowest number (less than 40 units) - in the Mykolaiv area.

Water resources. Releases of pollutants from industrial enterprises and municipal services, also runoffs from agricultural areas and territories occupied by landfills, have a significant negative impact on water bodies.

The largest \% of polluted water in the total amount of water discharged into water bodies are observed in the North $-30 \%$ and Central $27.4 \%$ of the regions.

At the first place in terms of a number of polluted centres are the Central region (61 units).

Land resources. The level of ploughing of the state territory is very high - over $54 \%$. The actual forest cover of the Ukraine territory is only $16 \%$, which is not enough to ensure ecological balance.

Level of agricultural ploughing lands is highest in the Southern, Central and Eastern regions, where it exceeds $\mathbf{7 0} \%$.

Minerals. The largest number of facilities for the extraction of mineral resources in Ukraine located in the East ( 965 sites) and the South (565 sites).

The task is to form an economic-organizational mechanism, which would contribute to its rationalization, accelerated the socio-economic 
growth of the regions, ensured the social efficiency of the use of components of "natural capital" in the reproduction process.

Keywords: region; nature management; pollution; anthropogenic impact.

Скаковская C. C. [1; ORCI ID: 0000-0002-3415-9613], ст. преподаватель

${ }^{1}$ Национальный университет водного хозяйства и природопользования, г. Ровно

\section{АНАЛИЗ ЭКОНОМИКО-ЭКОЛОГИЧЕСКОГО СОСТОЯНИЯ РЕГИОНОВ УКРАИНЫ}

Экологическую ситуацию в Украине, которая сложилась на сегодня, можно охарактеризовать как кризисную. Она формировалась в течение длительного периода из-за несоблюдения законов развития и воспроизводства природно-ресурсного потенциала, предпочтение отдавалось развитию в Украине сырье-добывающих, наиболее экологически опасных отраслей промышленного комплекса. Значительные изменения, которые происходили в структуре народного хозяйства, не повлекли уменьшения антропогенного воздействия на окружающую среду.

Ключевые слова: регион; природопользование; загрязнение; антропогенное воздействие. 